\title{
Obstructed labour at Usmanu Danfodiyo university teaching hospital Sokoto: a five-year review
}

\author{
Ahmed Yakubu'*, Tukur Dabo Sagir², Abubakar A. Panti' , Garba Jamila A. ${ }^{2}$, \\ Isah Usman Mani ${ }^{2}$, Anas Rabiu Funtua ${ }^{2}$, Aliyu Muhammed Chappa ${ }^{2}$, Mbakwe Markus ${ }^{2}$
}

\begin{abstract}
${ }^{1}$ Department of Obstetrics and Gynecology, Usmanu Danfodiyo University, Sokoto, Nigeria
${ }^{2}$ Department of Obstetrics and Gynecology, Usmanu Danfodiyo University Teaching Hospital, Sokoto, Nigeria
\end{abstract}

Received: 30 January 2020

Revised: 21 February 2020

Accepted: 29 February 2020

\section{*Correspondence:}

Dr. Ahmed Yakubu,

E-mail: ahmeddryakubu@yahoo.com

Copyright: ( $)$ the author(s), publisher and licensee Medip Academy. This is an open-access article distributed under the terms of the Creative Commons Attribution Non-Commercial License, which permits unrestricted non-commercial use, distribution, and reproduction in any medium, provided the original work is properly cited.

\section{ABSTRACT}

Background: Obstructed labour is an obstetric emergency and one of the major causes of maternal and perinatal morbidity and mortality in the developing countries, Nigeria inclusive. The aim of this study was to determine the prevalence, causes and feto-maternal outcome of cases of obstructed labour managed at Usmanu Danfodiyo University Teaching Hospital Sokoto from $1^{\text {st }}$ January, 2014 to $31^{\text {st }}$ December, 2018.

Methods: This was a retrospective review of all cases of obstructed labour managed at Usmanu Danfodiyo University Teaching Hospital Sokoto over 5 years. List of cases managed during the study period was obtained and case notes were retrieved. Relevant information such as age, booking status, parity, educational status, address, causes, mode of delivery and both maternal and foetal outcomes were obtained from the case notes. Data analysis was done using statistical package for social sciences version 22 (SPSS Inc, Chicago, IL, USA).

Results: A total two hundred and seventy-six cases of obstructed labour were managed out of the 15,452 total deliveries during the study period. This gives an obstructed labour prevalence of $1.79 \%$. The major cause of obstructed labour identified in this study was Cephalopelvic disproportion (74.6\%) and majority of the patients were delivered by emergency lower segment caesarean section (70.6\%). Up to $32.3 \%$ of the patients had no maternal complications and also $42.3 \%$ of them had live birth with no fetal complication. However, $20.2 \%$ of these patients had ruptured uterus and $37.9 \%$ of them had still birth, while $19.8 \%$ had live birth complicated by birth asphyxia.

Conclusions: This study has found that obstructed labour resulted in adverse maternal and perinatal outcome. Hence, there is need to prevent obstructed labour in order to avert this consequence.

Keywords: Nigeria, Obstructed labour, Sokoto

\section{INTRODUCTION}

Obstructed labour is a major cause of both maternal and perinatal morbidity and mortality in the developing countries including Nigeria. ${ }^{1-4}$ It is still a major public health problem in these countries.

Labour is considered obstructed when the presenting part of the fetus failed to progress into the birth canal despite strong adequate uterine contractions., ${ }^{5,6}$ It is a serious emergency situation. Apart from the maternal and perinatal death, obstructed labour is associated with number of debilitating and distressing maternal morbidities which includes uterine rupture, vesicovaginal fistula, recto-vaginal fistula, genital sepsis, gynaetresia, amenorrhea and impaired fertility. ${ }^{7,8}$ The most frequent causes of obstructed labour includes; cephalo-pelvic disproportion (CPD), malpresentation or 
malposition of the fetus (shoulder, brow or occipitoposterior position), locked twin or pelvic tumour etc. ${ }^{9,10}$

Obstructed labour is a serious emergency situation. Therefore, several interventions, such as the use of partograph to monitor labour and the provision of emergency obstetrics care services have been in place to reduce the scourge of obstructed labour and it is sequelae. However, the incidence of this condition is still worry some in the developing countries including Nigeria., ${ }^{71,12}$

Some of the contributing factors identified to make obstructed labour to be persistent in this setting are mainly socio-economic problems such as illiteracy, poverty, ignorance, belief in home deliveries under supervision of traditional birth attendants, maldistribution of health facilities, lack of good transportation system and aversion to surgery. ${ }^{10}$

The aim of the study was to identify the prevalence and outcome of the cases of obstructed labour managed at Usmanu Danfodiyo University Teaching Hospital Sokoto.

\section{METHODS}

This was a retrospective study of cases of obstructed labour managed at Usman Danfodiyo University Teaching Hospital, Sokoto, from $1^{\text {st }}$ January, 2014 to $31^{\text {st }}$ December, 2018. The list of cases of obstructed labour was obtained from the labour ward's register, operating theatre's register and the health records office of Usman Danfodiyo University Teaching Hospital Sokoto. The list of hospital numbers of all the cases was obtained and the case notes were retrieved from the medical records department. Relevant information that includes the age, booking status, parity, educational status, address, causes, mode of delivery and both maternal and foetal outcomes were obtained from the case notes.

\section{Inclusion criteria}

- All cases of obstructed labour that had all the relevant information required for the study.

\section{Exclusion criteria}

- Patients that had missing information in their folders were excluded.

\section{Statistical analysis}

Data analysis was done using statistical package for social sciences version 22 (SPSS Inc, Chicago, IL, USA).

\section{RESULT}

During this study period, there were a total of 15,452 deliveries out of which 276 were cases of obstructed labour and 248 folders were retrieved. The retrieval rate was $89.9 \%$. The prevalence of obstructed labour in this study was $1.79 \%$.

Table 1: Socio-demographic characteristics of
the patients.

\begin{tabular}{|c|c|c|c|}
\hline & Characteristics & Frequency & $\%$ \\
\hline \multirow{6}{*}{ Age } & $\begin{array}{l}\text { Less than } 20 \\
\text { years }\end{array}$ & 68 & $27.4 \%$ \\
\hline & 21 to 25 years & 72 & $29.0 \%$ \\
\hline & 26 to 30 years & 36 & $14.5 \%$ \\
\hline & 31 to 35 years & 30 & $12.1 \%$ \\
\hline & 36 to 40 years & 28 & $11.3 \%$ \\
\hline & 41 to 45 years & 14 & $05.7 \%$ \\
\hline \multirow{4}{*}{$\begin{array}{l}\text { Educational } \\
\text { status }\end{array}$} & $\begin{array}{l}\text { No formal } \\
\text { education }\end{array}$ & 201 & $81.1 \%$ \\
\hline & Primary & 40 & $16.1 \%$ \\
\hline & Secondary & 7 & $02.8 \%$ \\
\hline & Tertiary & 0 & $00.0 \%$ \\
\hline \multirow{2}{*}{$\begin{array}{l}\text { Area of } \\
\text { residence }\end{array}$} & Rural & 239 & $96.4 \%$ \\
\hline & Urban & 9 & $03.6 \%$ \\
\hline \multirow{5}{*}{ Parity } & 0 & 100 & $40.3 \%$ \\
\hline & 1 & 45 & $18.1 \%$ \\
\hline & 2 & 25 & $10.1 \%$ \\
\hline & 3 & 16 & $06.5 \%$ \\
\hline & 4 and above & 62 & $25.0 \%$ \\
\hline \multirow{2}{*}{$\begin{array}{l}\text { Booking } \\
\text { status }\end{array}$} & Booked & 18 & $07.3 \%$ \\
\hline & Not booked & 230 & $92.7 \%$ \\
\hline Total & & 248 & $100 \%$ \\
\hline
\end{tabular}

Table 2: Causes of obstructed labour at UDUTH, Sokoto.

\begin{tabular}{|lll|}
\hline Causes & Frequency & Percentage \\
\hline $\begin{array}{l}\text { Cephalopelvic } \\
\text { disproportion }\end{array}$ & 185 & $74.6 \%$ \\
\hline $\begin{array}{l}\text { Persistent occipitoposterior } \\
\text { position }\end{array}$ & 22 & $08.9 \%$ \\
\hline Face presentation & 10 & $04.1 \%$ \\
\hline Hydrocephalus & 9 & $03.6 \%$ \\
\hline Compound presentation & 8 & $03.2 \%$ \\
\hline Shoulder presentation & 6 & $02.4 \%$ \\
\hline Cervical fibroid & 4 & $01.6 \%$ \\
\hline Vaginal septum & 4 & $01.6 \%$ \\
\hline Total & 248 & $100 \%$ \\
\hline
\end{tabular}

Most of the patients (29\%) were in the age group of 21 to 25 years, followed by those that were less than 20 years $68(27.4 \%)$ and the least age group was those that were greater than 40 years $(5.7 \%)$. Majority of these patients $(81.1 \%)$ had no formal education and up to $96.4 \%$ of these patents were from the rural areas. Most of them 100 $(40.3 \%)$ were primigravidae and majority of them 230 $(92.7 \%)$ their pregnancies were not booked.

The most common cause of obstructed labour identified in this study was Cephalopelvic disproportion (CPD), 
which accounted for $74.6 \%$ of the cases. The causes of obstructed labour are shown in Table 2.

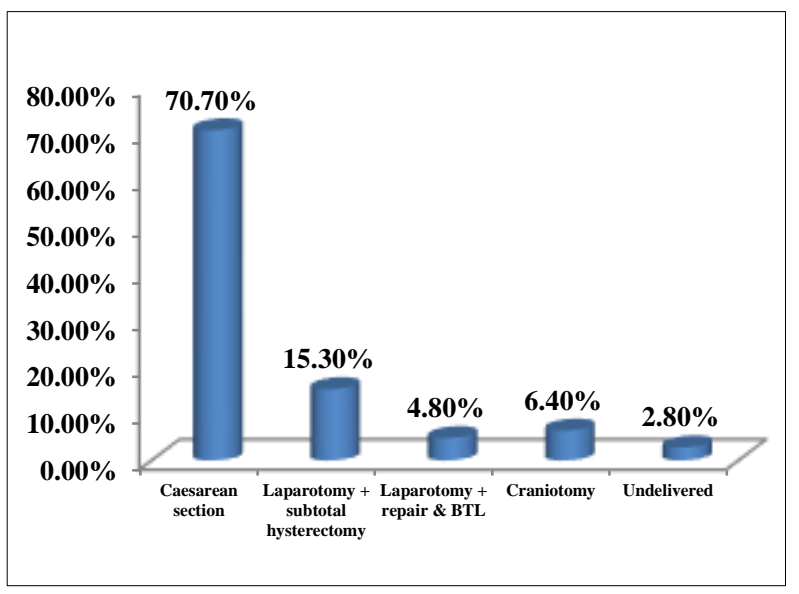

Figure 1: Modes of delivery among the patients with obstructed labour at UDUTH Sokoto.

Table 3: Maternal outcomes among the patients with obstructed labour at UDUTH Sokoto.

\begin{tabular}{|lll|}
\hline Maternal outcomes & Frequency & Percentage \\
\hline No complication & 80 & $32.3 \%$ \\
\hline Ruptured uterus & 50 & $20.2 \%$ \\
\hline Wound sepsis & 25 & $10.1 \%$ \\
\hline Postpartum haemorrhage & 20 & $08.1 \%$ \\
\hline Puerperal sepsis & 13 & $05.2 \%$ \\
\hline Vesico-vaginal fistula & 10 & $04.0 \%$ \\
\hline Obstetric palsy & 4 & $01.6 \%$ \\
\hline Maternal death & 17 & $06.8 \%$ \\
\hline $\begin{array}{l}\text { Mixed (more than one } \\
\text { complication) }\end{array}$ & 29 & $11.7 \%$ \\
\hline Total & 248 & $100 \%$ \\
\hline
\end{tabular}

Majority of these patients were delivered by caesarean section, while others were delivered by laparotomy + subtotal hysterectomy, laparotomy + repair of uterine rupture and bilateral tubal ligation, and craniotomy was done in $6.5 \%$ of the patients (Figure 1).

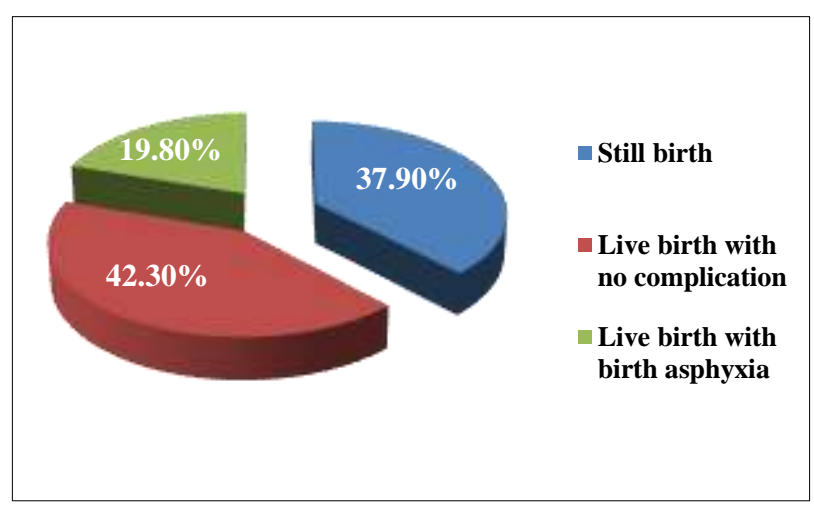

Figure 2: Fetal outcome among the cases of obstructed labour at UDUTH Sokoto.
Up to $32.3 \%$ of the patients had no complication. The complications encountered were ruptured uterus, sepsis, postpartum haemorrhage, and vesico-vaginal fistula. About $12 \%$ had had more than one complication. Maternal mortality occurred in about $7 \%$ of cases. The maternal outcome is shown in Table 3.

Majority of the patients $(42.3 \%)$ had live birth with no fetal complication, while $37.9 \%$ of them had still birth and the remaining $19.8 \%$ of them had live birth but with fetal birth asphyxia, shown in Figure 2.

\section{DISCUSSION}

The prevalence of obstructed labour of $1.79 \%$ in this study is lower compared to the prevalence of $2 \%$ obtained in a similar study done in the same institution in $2010 .^{10}$ It is also lower than that reported from Enugu $(2.7 \%)$, Ilorin (3.2\%) and Gombe (4\%). ${ }^{7,11,13}$ This may be as a result of increase in awareness and attendance of antenatal care by the pregnant women as well as improvement in obstetric services in the peripheral hospitals.

Majority of the cases of the obstructed labour in this study were in the age group of 21 to 25 years, followed by those that are less than 20 years. This is similar to the previous study done in same institution, where the highest number of cases belonged the age group 20 to 24 years; as well as a study done at Patna medical college hospital India, in which $48.24 \%$ of the cases were within the age range of 21 to 25 years. ${ }^{10,14}$ This may be because of high fertility within this age group and in those that are less than 20 years their pelvis may not be well developed, which may predispose them to obstructed labour.

Most of the pregnancies in these cases were not booked and this may be related to the fact that majority of the patients had no formal education and also from the rural areas. This is similar to other studies done in India and Bangladesh. ${ }^{14,15}$

Cephalopelvic disproportion was found to be the most common cause of obstructed labour in this study. This is similar to the previous studies done in Ilorin, Enugu and Gombe and also in Bangladesh. ${ }^{7,10,11,13,15}$ However, it differed from the findings in India, where malposition was the most common cause in $45.61 \%$ of the cases. ${ }^{14}$ Similarly, the most frequent mode of delivery of the cases in this study is lower segment caesarean section which is similar to the above mentioned studies. ${ }^{7,10,11,13,15}$

Up to $32.3 \%$ of the patients in this study had no maternal complications and also $42.3 \%$ of them had live birth with no fetal complication. This may be attributed to the presentation and prompt intervention. However, $20.2 \%$ of these patients had ruptured uterus and 37.9 of them had still birth. These may be as a result of delay in presentation and inappropriate interventions by quacks 
and other health personnel that increases the rate of complications.

\section{CONCLUSION}

Obstructed labour is a life-threatening obstetric condition that is associated with significant maternal as well as foetal morbidity and mortality. ${ }^{16}$ Therefore, health education, economic and social empowerment as well as early recognition and immediate intervention can go a long way in preventing this condition, its associated complications and improving the feto-maternal outcome. Several measures such as the use of partograph to monitor labour and provisions of emergency obstetrics care services also helps in the reduction of incidence of obstructed labour and its sequelae.

Funding: No funding sources

Conflict of interest: None declared

Ethical approval: The study was approved by the Institutional Ethics Committee

\section{REFERENCES}

1. National Population Commission and ICF Macro (2009) Nigeria Demographic and Health Survey Abuja, Nigeria, 2008. Available at: https://dhsprogramme.com/pubs/pdf/fr222.pdf Accessed on $11^{\text {th }}$ February 2020.

2. Ande A, Olagbuji B, Ezeanochie M. An audit of maternal deaths from a referral University teaching hospital in Nigeria: the emergence of HIV/AIDS as a leading cause. Niger Postgrad Med J. 2003;19:83-7.

3. Kabakyeng JK, Ostergren PO, Turyakira E, Mukasa PK, Pettersson KO. Individual and health facility factors and the risk for obstructed labour and its adverse outcomes in South-west Uganda. BMC Preg Childbirth. 2011;11:73.

4. Sheikh S. frequency of obstructed labour in teenage pregnancy. Nepal J Obstet Gynaecol. 2013:7(1):3740.

5. Alkire L, Blake C. Obstructed labour and caesarean delivery: the cost and benefit of surgical intervention. PloS One. 2012;7(4):e34595.

6. Carmen D, Abouzahr C. Global burden of obstructed labour in the year 2000. Evidence and information for policy (EIP), World Health Organization, Geneva; 2012:1-17.

7. Nwogu-Ikojo EE, Nweze SO, Ezegwui HU. Obstructed labour in Enugu Nigeria. J Obstet Gynaecol. 2008;28(6):596-9.

8. John CT, Uzoigwe SA. Abnormal labour. In: Ikpeze OC (ed). Fundamentals of obstetrics and gynaecology. $1^{\text {st }}$ Edition Africana first publisher PLC; 2009:108-115.

9. Shaikh SR, Memon KN, Usman G. Obstructed labour; risk factors and outcome among women delivered in a tertiary care hospital. Professional Med J. 2015;22(5):615-20.

10. Nwobodo EI, Ahmed Y. Obstructed labour; a public health problem in Sokoto, Nigeria. Sahel Med J. 2011;14(3):140-2.

11. Melah GS, El-Nafaty AU, Massa AA, Audu BM. Obstructed labour: a public health problem in Gombe state Nigeria. J Obstet Gynaecol. 2003;23:369-73.

12. Adeoye IS, Dimejesi I, Onoh R, Bartholomew O, Ezeanochie M, Kalu C. Obstructed labour in South East Nigeria revisited: a multicentre study on maternal socio-demographic and clinical correlates. J Women's Health Care. 2014;3:160.

13. Aboyeji AP, Fawole AA. Obstructed labour in Ilorin Nigeria: a one year prospective study. Nig Med Pract. 1999;38(1-3):27-8.

14. Ranjana D, Anjana S. Incidence, causes and fetomaternal outcomes of obstructed labour in a tertiary health care centre. Int J Reprod Contracept Obstet Gynaecol. 2017;6(7):2817-21.

15. Islam JA, Ara G, Choudhury FR. Risk factors and outcome of obstructed labour at a tertiary care hospital. J Shaheed Suhrawardy Med Coll. 2012;4(2):43-6.

16. Wagaarachchi PT, Graham WJ, Penney GC. Holding up a mirror: Changing obstetric practice through criteria based clinical audit in developing countries. Int J Gynaecol Obstet. 2001;74(2):119.

Cite this article as: Yakubu A, Sagir TD, Panti AA, Jamila GA, Mani IU, Funtua AR, et al. Obstructed labour at Usmanu Danfodiyo university teaching hospital Sokoto: a five-year review. Int J Reprod Contracept Obstet Gynecol 2020;9:1503-6. 